\title{
Corn grain-processing method interacts with calcium salts of palm fatty acids supplementation on milk production and energy balance of early-lactation cows grazing tropical pasture
}

\author{
Fernanda Batistel, ${ }^{* 1}$ Jonas de Souza, ${ }^{\star} \dagger$ and Flávio Augusto Portela Santos ${ }^{* 2}$ \\ *Department of Animal Science, University of São Paulo, Piracicaba, São Paulo, 13418-900, Brazil \\ †Department of Animal Science, Michigan State University, East Lansing 48824
}

\begin{abstract}
The objective of our study was to investigate the associative effects of feeding Ca salts of palm fatty acids (FA) and corn grain-processing method on production, nutrient digestibility, energy balance, and carryover effects of early-lactation dairy cows grazing a tropical pasture. Treatment diets were offered from 3 to $16 \mathrm{wk}$ postpartum (treatment period), in which all cows grazed elephant grass (Pennisetum purpureum L. Cameroon) and treatments were added to a concentrate supplement. Treatments were flint corn grain-processing method either as fine ground (FGC) or steam-flaked (SFC) associated with Ca salts of palm FA supplementation either not supplemented or supplemented (CSPO). From 17 to 40 wk postpartum (carryover period) all cows received a common diet fed as total mixed ration. During the treatment period, a tendency for an interaction between CSPO and corn grain-processing method were observed for milk yield, milk fat yield, and energy-corrected milk (ECM), as CSPO caused them to increased to a greater extent in the FGC diet compared with the SFC diet. Furthermore, a tendency for an interaction between CSPO and corn grain-processing method was observed for body weight change, because CSPO increased body weight loss in the FGC diet but not in the SFC diet. The CSPO increased milk yield, milk fat yield, $3.5 \%$ fat-corrected milk, ECM, and cumulative milk yield compared with not supplemented. Also, CSPO increased energy intake, milk energy output, and energy partitioning toward milk, whereas reduced energy was allocated to body reserves. The SFC increased milk yield, ECM, milk protein yield, milk casein yield, and cumulative milk yield, and decreased milk urea $\mathrm{N}$ compared with FGC. The SFC compared with FGC
\end{abstract}

Received December 21, 2016.

Accepted March 8, 2017.

${ }^{1}$ Current address: Department of Animal Sciences, University of Illinois, Urbana 61801.

${ }^{2}$ Corresponding author: fapsantos@usp.br also increased body condition score and body weight change, and increased energy partitioning toward body reserves. During the carryover period, an interaction between CSPO and corn grain-processing method was observed for milk yield, which occurred because CSPO maintained higher milk yield in the FGC diet but not in the SFC diet. Therefore, in the carryover period, the additive effect between SFC and CSPO that occurred in the treatment period was not maintained throughout the carryover period. However, CSPO increased yields of milk fat, protein, casein as well as fat-corrected milk and ECM. In conclusion, corn grain-processing method interacts with CSPO supplementation on production responses and carryover effects of grazing cows. When CSPO was fed in the FGC diet, milk production increased to a greater extent than when fed in the SFC diet, but also caused greater mobilization of reserves at early lactation. This suggests an interaction between fat supplementation and corn grain-processing method on energy partitioning of dairy cows. Also, both supplementation with CSPO and SFC were effective strategies to increase energy intake and yields of milk and milk solids. The carryover effect on milk production was greater for CSPO supplementation than corn grain-processing method, whereas feeding SFC diets had lower mobilization of reserves and less body weight and body condition score variation throughout lactation.

Key words: calcium salts, corn processing, palm fatty acids, steam-flaked corn

\section{INTRODUCTION}

Following parturition, cows enter a period of negative energy balance because they cannot consume enough nutrients to support lactation (NRC, 2001). Under grazing conditions, this negative energy balance may even be greater as a consequence of a lower DMI compared with cows consuming a TMR diet (Muller and Fales, 1998), as well as the greater requirement for maintenance because of more physical activity 
(Dohme-Meier et al., 2014). This state of negative energy balance results in increased mobilization of body reserves, and optimizing energy intake during the early lactation period is important to provide sufficient available energy to support milk production and avoid pronounced reserves mobilization (McCarthy et al., 2015). Approaches to increase energy intake of postpartum cows include increasing dietary energy density by raising starch digestibility or by fatty acid (FA) supplementation.

Feeding concentrate based on cereal grains is the most common strategy used to enhance energy intake in pasture-based systems (Bargo et al., 2003). Starch is an important source of fuels for lactating dairy cows and for microbial protein production in the rumen (Oba and Allen, 2003). However, slug feeding higher amounts of starch-based supplements may result in decreased ruminal pH (Wales and Doyle 2003), NDF digestibility (Wales et al., 2004), and total DMI (Auldist et al., 2013). Rather than increasing the amount of starch, increased starch fermentability through extensive grain processing (e.g., steam-flaking) may improve total-tract starch digestibility and the efficiency of milk production (Owens and Soderlund, 2007). Theurer et al. (1999) observed that steam-flaking of dent corn compared with dry- and steam-rolling of corn consistently improved milk production and milk protein yield. However, these results were obtained in experiments conducted with dent corn grain, which is less vitreous than the flint corn grain typically grown and fed in several countries (e.g., Brazil, Colombia, and Northern Europe; Correa et al., 2002). Because vitreousness has been negatively correlated with ruminal starch availability (Philippeau and Michalet-Doreau, 1998), extensive processing of corn grain would be expected to be of greater benefit with flint than with dent corn. However, to our knowledge the potential benefit of extensively flint corn processing has not been evaluated in dairy cows.

Additionally, supplemental fat can be used to increase the energy density of diets and replace, at least in part, cereal grain. Although fat supplementation has been shown to increase milk production in housed systems with cows receiving TMR (Rabiee et al., 2012), the potential response of supplemental fat in pasturebased diets is still not well described (Schroeder et al., 2004), particularly for cows grazing on tropical pastures. Tropical grasses are commonly described as lowquality forages, but with higher potential for herbage mass accumulation (Santos et al., 2014). Low-quality tropical grasses, which have high fiber content and low DM digestibility, have a negative effect on voluntary feed intake and consequent animal performance (Moore and Mott, 1973). This would be especially important for early-lactation high-producing cows due to their greater nutrient requirements. With cows grazing on tropical pastures, de Souza et al. (2017) observed that supplementation with Ca salts of palm FA was an effective strategy to increase energy intake, milk production, and yield of milk components, as well as having a positive carryover effect when fed to early-lactation cows replacing fine ground corn. The effectiveness of Ca salts to reduce the deleterious effects of feeding fat to ruminal population is largely dependent on ruminal $\mathrm{pH}$ and the degree of unsaturation of the fat source (Sukhija and Palmquist, 1990). An increase in starch fermentability through extensive grain processing may lead to a reduced ruminal pH (Krause and Combs, 2003). Likewise, increasing starch fermentability resulted in greater accumulation of CLA isomers responsible for milk fat depression (Lascano et al., 2016). As diets that induce milk fat depression have been associated with repartitioning of energy toward adipose tissue (Harvatine et al., 2009), starch fermentability may reduce the stability of Ca salts supplements and potentially affect the response and energy partitioning of dairy cows to Ca salts of palm FA supplementation.

Therefore, the objective of our study was to investigate the associative effects of feeding Ca salts of palm FA and corn grain-processing method on production, nutrient digestibility, energy balance, and carryover effect of early-lactation dairy cows grazing tropical pasture. We hypothesized that high-producing, earlylactation dairy cows grazing on tropical pastures have a greater negative energy balance and feeding more fermentable starch and supplemental fat in the diet could be advantageous, with potentially greater milk yield throughout the entire lactation. We also postulated that the production responses to Ca salts of palm FA supplement would be affected by the corn grainprocessing method because of ruminal fermentation and energy partitioning.

\section{MATERIALS AND METHODS}

The study was conducted in Piracicaba, São Paulo, Brazil. All procedures involving the animals were approved by the Ethical Committee for Animal Research of the University of São Paulo, Piracicaba.

\section{Animals and Treatments}

Forty-four multiparous dairy cows $(24$ Holstein $\times$ Gir and 20 Jersey $\times$ Holstein), with $494 \pm 55 \mathrm{~kg}$ of BW, $3.20 \pm 0.12$ BCS, milk yield of $19.2 \pm 2.8 \mathrm{~kg}$, and $17 \pm$ 2.2 DIM were used. Cows were blocked by breed, and cows within each block were balanced by parity, BCS, and previous lactation 305-d milk production. Animals were randomly assigned to 4 treatments arranged in a 
$2 \times 2$ factorial design and the dietary treatments were offered from 3 to $16 \mathrm{wk}$ postpartum (treatment period). Treatments were corn grain-processing method either as fine ground (FGC) or steam-flaked (SFC; density of $360 \mathrm{~g} / \mathrm{L}$ ) and Ca salts of palm FA supplementation either not supplemented $(\mathbf{C O N})$ or supplemented (CSPO; $400 \mathrm{~g}$ of CSPO cow/d, Nutri Gordura Lac, Nutricorp Inc., Araras, São Paulo, Brazil). This level of fat supplementation was adopted to provide $2.0 \%$ of FA of diet DM, assuming an intake of $17.5 \mathrm{~kg} / \mathrm{d}$ and $85 \%$ of FA in the Ca salts supplement (NRC, 2001). From 17 to 40 wk postpartum (carryover period), all cows received a common diet fed as TMR. All diets were formulated to meet the predicted requirements according to the NRC (2001).

During the treatment period (3 to 16 wk postpartum), all cows were rotationally grazed elephant grass (Pennisetum purpureum L. Cameroon) as one herd and the treatments were added to a concentrate supplement $(8 \mathrm{~kg}$ of DM/d). The treatments were fed individually in 2 equal feedings at 0400 and $1600 \mathrm{~h}$ before milking. Chemical composition and in vitro starch degradability of corn processed either as fine ground or steam-flaked used in dietary treatments is presented in Table 1. The ingredients and chemical composition of the concentrate mixes used are presented in Table 2. Cows were milked twice a day after concentrate feeding. Distance from pastures to the milking parlor averaged $0.4 \mathrm{~km}$ (ranged between 0.2 and $0.7 \mathrm{~km}$ ). During the treatment period, average temperature was $23.0 \pm 2.3^{\circ} \mathrm{C}$ and rainfall was $264 \pm 55.5 \mathrm{~mm}$.

The 6.0 ha of pasture used in this experiment were fertilized with $60 \mathrm{~kg}$ of N/ha after each grazing. The experimental cows were allocated to a new paddock with 2,000 $\mathrm{m}^{2}$ every day, after evening milking, with free access to natural shade and fresh water. Elephant grass was managed in a rotational grazing system based on canopy height; the entry height was $103 \mathrm{~cm}$, previously determined as the point for the canopy to intercept $95 \%$ of the incident light (Voltolini et al., 2010). The experimental group of cows grazed the canopy down to an average of $66 \pm 3.2 \mathrm{~cm}$ (Supplemental Table S1; https://doi.org/10.3168/jds.2016-12503). Subsequently, a group of dry cows and heifers were used to graze down the pasture to final postgrazed height $(40 \pm 4.2$ $\mathrm{cm})$. The average grazing interval was $24 \pm 2.5 \mathrm{~d}$.

\section{Experimental Measures and Sample Collection During the Treatment Period}

Sward height was measured every day at 20 randomized points before animals entrance to the paddock and after they left. Pre- and postgrazing forage mass were measured in 2 paddocks every week by clipping the forage inside of 4 rectangles $(1.5 \times 0.75 \mathrm{~m})$ at $3 \mathrm{~cm}$ above ground level from sites that represented the mean sward height of the paddock. Total forage mass was weighed, and 2 representative subsamples (500 g) were taken. The first subsample was dried in a forced-air oven at $55^{\circ} \mathrm{C}$ for $72 \mathrm{~h}$ for determining DM content. The second subsample was separated into leaves, stems, and senescent material. Concentrate and forage ingredients were collected for chemical composition weekly. Handplucked forage samples were taken according to De Vries (1995) at 25 randomized points per paddock in 3 paddocks per week before cows had access. All samples were dried in a forced-air oven at $55^{\circ} \mathrm{C}$ for $72 \mathrm{~h}$, ground through a 1-mm screen (Wiley mill, Thomas Scientific, Philadelphia, PA), and composited by month.

During the treatment period, forage intake and nutrient digestibility were measured at wk 6,10 , and 14 postpartum from total fecal excretion and feed indigestibility. To determine fecal excretion, $\mathrm{TiO}_{2}$ was dosed twice a day $(20 \mathrm{~g} /$ cow per day) after each milking for 15 d (de Souza et al., 2015). Fecal grab samples were collected after morning and afternoon milking from the last $5 \mathrm{~d}$, and immediately frozen in liquid $\mathrm{N}$ to avoid starch degradation, and then stored in a $-20^{\circ} \mathrm{C}$ freezer. Subsequently, samples were thawed, dried at $55^{\circ} \mathrm{C}$ in a forced-air oven, ground through a 1-mm screen (Wiley mill, Thomas Scientific), and composited by cow.

Cows were milked twice a day at 0600 and $1600 \mathrm{~h}$ and milk yield was recorded daily. Milk samples from both milking sections were collected once a week and preserved with a bronopol preservative pill. An additional milk sample was collected at each milking every $30 \mathrm{~d}$ and stored without preservative at $-20^{\circ} \mathrm{C}$ for determination of milk FA profile. Cows were weighed weekly after the morning milking. Body condition was scored weekly by 2 trained investigators on a 5 -point scale, where $1=$ thin and $5=$ fat, as described by Wildman et al. (1982).

Table 1. Composition of corn processed either as fine ground or steam flaked used in dietary treatments

\begin{tabular}{lcc}
\hline Item, \% DM (unless noted) & $\begin{array}{c}\text { Dry } \\
\text { ground } \\
\text { corn }\end{array}$ & $\begin{array}{c}\text { Steam- } \\
\text { flaked } \\
\text { corn }\end{array}$ \\
\hline NDF & 2.75 & 2.84 \\
ADF & 1.21 & 1.24 \\
CP & 8.61 & 8.24 \\
Starch & 79.2 & 77.8 \\
7-h Starch degradability, ${ }^{1}$ \% starch & 35.4 & 68.2 \\
\hline
\end{tabular}

${ }^{1}$ Measured as the starch disappearance after in vitro incubation for 7 h. In vitro procedure was conducted according to Gouvêa et al. (2016). 
Table 2. Composition of the forage and experimental concentrates

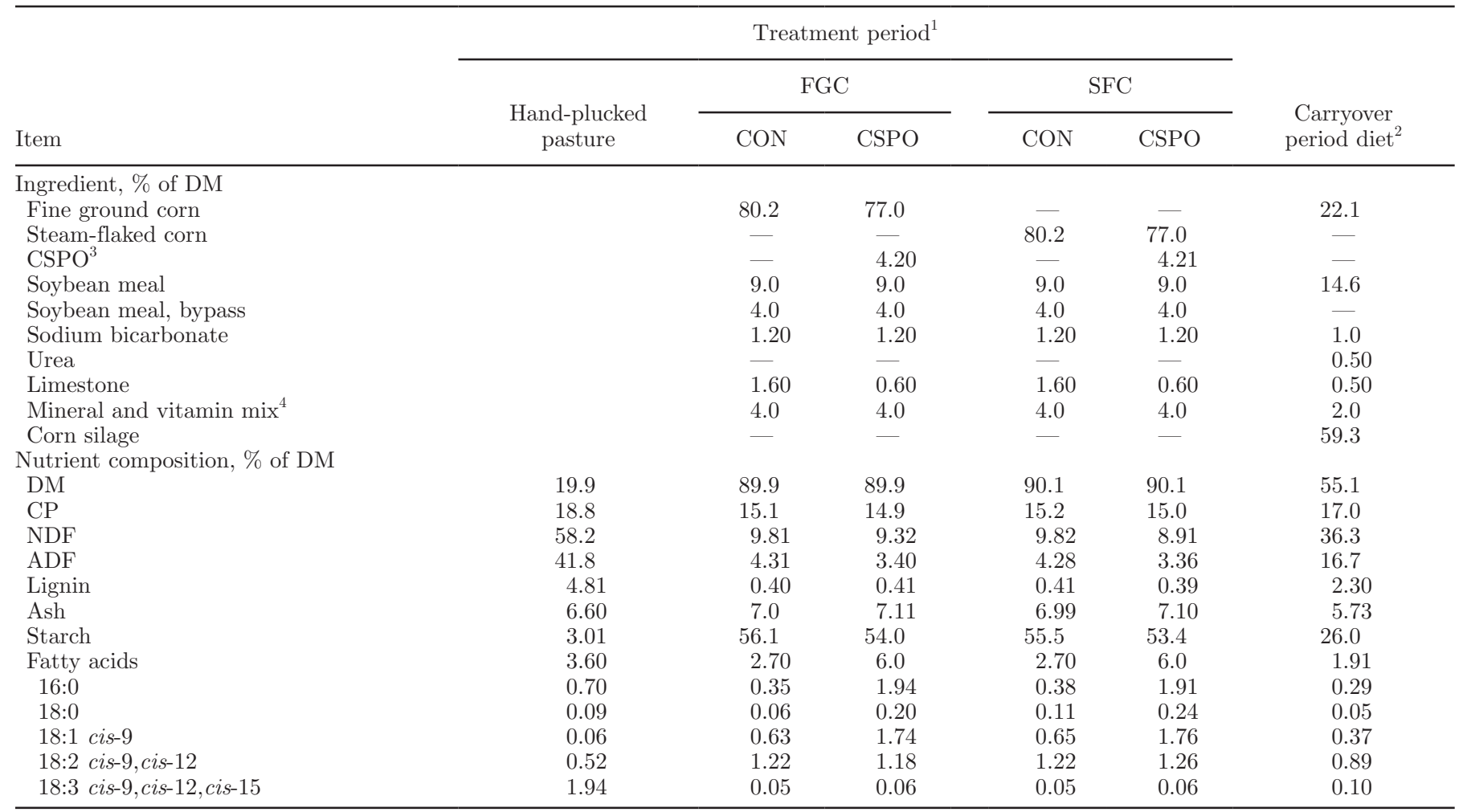

${ }^{1}$ During the treatment period ( 3 to 16 wk postpartum) cows grazed elephantgrass (Pennisetum purpureum L. Cameroon) and received treatments as a concentrate supplement. Concentrate fed during treatment period contained either fine ground corn (FGC) or steam-flaked corn (SFC) associated or not with Ca salts of palm oil supplementation [not supplemented (CON) or supplemented (CSPO)].

${ }^{2}$ During the carryover period (17 to 40 wk postpartum) cows received a common diet fed as TMR.

${ }^{3}$ Ca salts of palm oil (CSPO; Nutri Gordura Lac, Nutricorp Inc., Araras, São Paulo, Brazil) 84.9\% fatty acids (48.6\% C16:0, 4.40\% C18:0, 34.3\% C18:1 cis-9, $5.5 \%$ C18:2 cis-9, cis-12, and others $<2 \%$ each).

${ }^{4}$ Provided the following per kilogram of product DM: $250 \mathrm{~g}$ of Ca, $45 \mathrm{~g}$ of P, $65 \mathrm{~g}$ of Na, $10 \mathrm{~g}$ of $\mathrm{Mg}, 10 \mathrm{~g}$ of S, 2,375 mg of Mn, 2,375 mg of Zn, $562 \mathrm{mg}$ of $\mathrm{Cu}, 12.5 \mathrm{mg}$ of $\mathrm{Co}, 31 \mathrm{mg}$ of I, $15.8 \mathrm{mg}$ of Se, 200,000 IU of vitamin A, 50,000 IU of vitamin $\mathrm{D}_{3}$, and 1,250 IU of vitamin E.

\section{Experimental Measures and Sample Collection During the Carryover Period}

From 17 to 40 wk postpartum (carryover period) all cows received a common diet fed as TMR once a day at $0900 \mathrm{~h}$. Cows were milked twice a day at 0700 and $1500 \mathrm{~h}$ and milk yield was recorded every day. Milk samples from both milking procedures were collected once a week and preserved with a bronopol preservative pill. Feed ingredients were collected weekly and stored at $-20^{\circ} \mathrm{C}$. Subsequently, samples were thawed, dried at $55^{\circ} \mathrm{C}$ in a forced-air oven, ground through a $1-\mathrm{mm}$ screen (Wiley mill, Thomas Scientific), and composited by month. Cows were weighed and BCS recorded weekly as previously described.

\section{Sample Analysis and Calculations}

Composite forage, concentrate, and fecal samples were analyzed for DM (drying samples in an oven at $105^{\circ} \mathrm{C}$ for $24 \mathrm{~h}$ ), ash (AOAC International, 2005; method 942.05), total N content (Leco FP-2000 N Analyzer; Leco Instruments Inc., St. Joseph, MI), NDF (Van Soest et al., 1991) with sodium sulfite and heat-stable $\alpha$-amylase for concentrate samples, $\mathrm{ADF}$ and lignin (AOAC International, 2005; method 973.18), and gross energy by bomb calorimeter (Parr Instrument Inc., Moline, IL). Starch was measured by an enzymatic method (Karkalas, 1985) after samples were gelatinized with sodium hydroxide, glucose concentration was measured with glucose oxidase (Glucose kit \#G0543; Sigma Chemical Co., St. Louis, MO), and absorbance was determined with a spectrophotometer (UV-1601 PC, Shimadzu, Kyoto, Japan).

Milk samples were analyzed for fat, protein, lactose, TS, and MUN using infrared procedures (Foss 4000; Foss North America, Eden Prairie, MN). Milk samples for FA profile were extracted according to Hara and Radin (1978) using a 3:2 (vol:vol) mixture of hexane and isopropanol followed by $67 \mathrm{~g} / \mathrm{L}$ sodium sulfate solu- 
tion. The fat cake was previously obtained by milk centrifugation at $15,000 \times g$ for $30 \mathrm{~min}$ at $8^{\circ} \mathrm{C}$. Milk FAME were obtained by base-catalyzed transmethylation using a freshly prepared methylation reagent according to Christie (1982) with modifications (Chouinard et al., 1999). The FAME were determined by GC (model 6890 N; Agilent Technologies Brasil Ltda., Barueri, Brazil) fitted with a flame-ionization detector and equipped with a CP-Sil 88 fused-silica capillary column $(100 \mathrm{~m} \times$ $0.25 \mathrm{~mm} \times 0.2 \mu \mathrm{m}$ film thickness; Varian Inc., Mississauga, ON, Canada). The yield of individual FA in milk fat was calculated by correcting for glycerol content according to Schauff et al. (1992), and other milk lipid classes according to Glasser et al. (2007).

Forage intake was calculated from total fecal excretion and feed indigestibility. To determine fecal excretion, fecal samples were analyzed for titanium concentration according to Myers et al. (2004). To determine indigestibility, the indigestible NDF (iNDF) content of forage, concentrate, and fecal samples was determined according to Huhtanen et al. (1994). The iNDF contents of forage and concentrate were divided by the iNDF content in the feces of each cow to calculate the indigestibility of feeds for each animal. Total fecal excretion, fecal excretion coming from the concentrate, and forage intake were calculated according to de Souza et al. (2015).

Energy values were calculated based on NRC (2001) as described by Harvatine and Allen (2006) as follows: digestible energy intake $=$ gross energy intake $\times$ gross energy digestibility; $\mathrm{NE}_{\mathrm{L}}$ intake was calculated from digestible energy according to NRC (2001). Milk $\mathrm{NE}_{\mathrm{L}}$ (Mcal/ d) was calculated as milk yield $(\mathrm{kg}) \times[0.0929$ $\times($ fat $\%)+0.0563 \times($ true protein $\%)+0.0395 \times$ (lactose \%)] (NRC, 2001); $\mathrm{NE}_{\mathrm{L}} \mathrm{BW}$ change was calculated according to $\mathrm{NRC}$ (2001); and $\mathrm{NE}_{\mathrm{L}}$ available for Maintenance $=\mathrm{NE}_{\mathrm{L}}$ intake $-\mathrm{NE}_{\mathrm{L}}$ milk $-\mathrm{NE}_{\mathrm{L}} \mathrm{BW}$ change. Energy partitioning was calculated as described by Boerman et al. (2015) as percent allocated to milk, maintenance, or body gain $=[$ milk energy output, maintenance, or body tissue gain $/\left(\mathrm{NE}_{\mathrm{L}}\right.$ intake $\left.\left.\times 100\right)\right]$.

\section{Statistical Analyses}

Data were analyzed separately for treatment period (from 3 to 16 wk postpartum) and carryover period (from 17 to 40 wk postpartum). All weekly or monthly data were analyzed using the MIXED procedure of SAS v.9.4 (SAS Institute Inc., Cary, NC) according to the following model as repeated measures:

$$
\begin{aligned}
\mathrm{Y}_{\mathrm{ijk} k}=\mu & +\mathrm{b}_{\mathrm{i}}+\mathrm{C}_{\mathrm{j}}+\mathrm{F}_{\mathrm{k}}+\mathrm{CF}_{\mathrm{jk}}+\mathrm{T}_{1}+\mathrm{CT}_{\mathrm{jl}} \\
& +\mathrm{FT}_{\mathrm{kl}}+\mathrm{CFT}_{\mathrm{jkl}}+\mathrm{e}_{\mathrm{ijk} \mathrm{kl}},
\end{aligned}
$$

where $Y_{i j k l}$ is the variable of interest; $\mu$ is the overall mean; $b_{i}$ is the random effect of block ( $i=1$ to 11 ); $C_{j}$ is the fixed effect of corn grain-processing method $(\mathrm{j}=$ FGC or SFC); $F_{k}$ is the fixed effect of CSPO supplementation $(\mathrm{k}=\mathrm{CON}$ or $\mathrm{CSPO}) ; \mathrm{CF}_{\mathrm{jk}}$ is the fixed effect of interaction between corn grain-processing method and CSPO supplementation; $\mathrm{T}_{1}$ is the fixed effect of time (day, week or month); $\mathrm{CT}_{\mathrm{j} 1}$ is the interaction between corn grain-processing method and time; $\mathrm{FT}_{\mathrm{kl}}$ is the interaction between CSPO and time; $\mathrm{CFT}_{\mathrm{jkl}}$ is the interaction between corn grain-processing method, CSPO, and time; and $\mathrm{e}_{\mathrm{ijkl}}$ is the residual error. Normality of the residuals was checked with normal probability and box plots and homogeneity of variances with plots of residuals versus predicted values. Unless otherwise specified, first-order autoregressive was the covariate structure used for analysis because it resulted in the lowest Bayesian information criterion for most of the variables measured. Denominator degrees of freedom were adjusted by the Kenward-Rogers method. Interactions with time were removed from the model when nonsignificant $(P>0.20)$ and a reduced model was used to determine treatment effects. Significances was determined at $P \leq 0.05$ and tendencies at $P \leq 0.10$. Two cows were removed from analysis in the carryover period because they developed mastitis during 2 consecutive weeks.

\section{RESULTS}

\section{Production Responses During the Treatment Period}

The CSPO increased $(P<0.01)$ milk yield during the treatment period, as well as yield of fat, protein, lactose, and casein compared with CON (Table 3). In addition, CSPO increased $(P<0.01) 3.5 \%$ FCM and ECM by $3.1 \mathrm{~kg} / \mathrm{d}$, cumulative milk yield by $264 \mathrm{~kg}$, and feed efficiency compared with CON. In contrast, CSPO decreased milk protein content $(P=0.04)$ and BCS $(P$ $=0.01)$ and tended to decrease casein content $(P=$ $0.10)$ and BW change $(P=0.08)$ compared with CON. Likewise, a time $\times$ CSPO interaction $(P=0.03)$ was observed for $\mathrm{BW}$ as a result of CSPO having a lower BW at wk 7 and 12 postpartum compared with CON (Figure 1).

During the treatment period, SFC increased milk yield $(P=0.03)$, milk protein content $(P<0.01)$, casein content $(P<0.01)$, milk protein yield $(P<0.01)$, milk lactose yield $(P<0.01)$, milk casein yield $(P<0.01)$, and $\operatorname{ECM}(P=0.02)$, and tended to increase $3.5 \%$ FCM $(P=0.10)$ compared with FGC. Furthermore, cows that received SFC increased $(P=0.04)$ the cumulative milk yield during treatment and feed efficiency compared with FGC. In contrast, cows supplemented 
with SFC had lower milk fat content $(P=0.01)$ and MUN $(P<0.01)$ than FGC cows. The SFC increased BCS $(P=0.01)$ and BW change $(P=0.01)$ compared with FGC. A time $\times$ corn grain-processing method was observed for BW $(P=0.02)$ because SFC increased BW between the wk 12 and 16 postpartum compared with FGC (Figure 1).

We observed an interaction $(P<0.01)$ between CSPO and corn grain-processing method for milk fat content because CSPO increased milk fat content in FGC diet, whereas it reduced milk fat content in the SFC diet. A tendency for an interaction $(P=0.10)$ between CSPO and corn grain-processing method was observed for milk yield due to CSPO increasing milk yield to a greater extent in the FGC diet compared with the SFC diet. In addition, a tendency for an interaction $(P=$ 0.07) between CSPO and corn grain-processing method was observed for milk protein content because CSPO reduced milk protein content in the FGC diet but not in the SFC diet. A tendency for an interaction between CSPO and corn grain-processing method were also observed for milk fat yield $(P=0.07)$ and for ECM $(P=$ $0.10)$ due to CSPO increasing milk fat yield and ECM to a greater extent in the FGC diet compared with the SFC diet. In addition, a tendency for an interaction between CSPO and corn grain-processing method was observed for BW change $(P=0.07)$ and BCS $(P=$ 0.06 ) because CSPO reduced BW and BCS in the FGC diet but had no effect in the SFC diet.

\section{Production Responses During the Carryover Period}

In the carryover period, CSPO increased $(P \leq 0.01)$ yield of milk, milk fat, milk protein, and milk lactose compared with CON (Table 4). However, no differences in milk composition were observed $(P>0.10)$. Cows supplemented with CSPO had higher $(P=0.01) 3.5 \%$ FCM and ECM as well as cumulative milk yield than CON. Moreover, CSPO tended to reduce BW compared with CON during the carryover period $(P=0.06)$.

Although SFC tended to increase $(P=0.10)$ milk yield compared with FGC, no differences in contents and yields of milk components were observed $(P>$ $0.10)$. However, SFC tended to increase $3.5 \%$ FCM $(P$ $=0.10)$, ECM $(P=0.08)$, and cumulative milk yield by $103 \mathrm{~kg}(P=0.08)$ compared with FGC. Also, SFC tended to increase BCS $(P=0.09)$ and BW change $(P$ $=0.09)$ compared with CON.

An interaction between CSPO and corn grain-processing method was observed for milk yield in the car-

Table 3. Corn grain-processing method and Ca salts of palm fatty acids supplementation on production, milk composition, and feed efficiency of dairy cows during the treatment period (3 to 16 wk postpartum)

\begin{tabular}{|c|c|c|c|c|c|c|c|c|}
\hline Item & \multicolumn{4}{|c|}{ Treatment $^{1}$} & SEM & \multicolumn{3}{|c|}{$P$-value ${ }^{2}$} \\
\hline \multicolumn{9}{|l|}{ Yield, $\mathrm{kg} / \mathrm{d}$} \\
\hline Milk & 20.3 & 24.0 & 22.3 & 25.1 & 0.65 & 0.03 & $<0.01$ & 0.10 \\
\hline Fat & 0.68 & 0.82 & 0.73 & 0.80 & 0.04 & 0.35 & $<0.01$ & 0.07 \\
\hline Casein & 0.47 & 0.53 & 0.56 & 0.61 & 0.02 & $<0.01$ & $<0.01$ & 0.22 \\
\hline $35 \% \mathrm{FCM}^{3}$ & 19.7 & 23.6 & 21.4 & 23.8 & 0.68 & 0.10 & $<0.01$ & 0.12 \\
\hline $\mathrm{ECM}^{4}$ & 20.0 & 23.8 & 22.1 & 24.6 & 0.71 & 0.02 & $<0.01$ & 0.10 \\
\hline Cumulative milk yield, $\mathrm{kg}$ & 1,908 & 2,163 & 2,028 & 2,301 & 52.9 & 0.04 & $<0.01$ & 0.90 \\
\hline Feed efficiency ${ }^{5}$ & 1.38 & 1.51 & 1.42 & 1.54 & 0.05 & 0.04 & $<0.01$ & 0.94 \\
\hline \multicolumn{9}{|c|}{ Milk composition, \% (unless noted) } \\
\hline Fat & 3.33 & 3.40 & 3.26 & 3.18 & 0.05 & 0.01 & 0.33 & $<0.01$ \\
\hline BW change, $\mathrm{kg} / \mathrm{d}$ & 0.05 & 0.01 & 0.14 & 0.11 & 0.02 & 0.05 & 0.08 & 0.07 \\
\hline $\mathrm{BCS}$ & 3.10 & 3.00 & 3.20 & 3.17 & 0.04 & 0.02 & 0.01 & 0.06 \\
\hline
\end{tabular}

${ }^{1}$ Concentrate fed during the treatment period contained either fine ground corn (FGC) or steam-flaked corn (SFC) associated or not with Ca salts of palm oil supplementation [not supplemented (CON) or supplemented (CSPO)].

${ }^{2} P$-values associated with the main effect of corn processing (corn), main effect of CSPO supplementation (fat), and the interaction between corn processing and CSPO supplementation.

${ }^{3} 3.5 \% \mathrm{FCM}=[(0.4324 \times$ milk yield $)+(16.216 \times$ fat yield $)]$.

${ }^{4} \mathrm{ECM}=[(0.327 \times \mathrm{kg}$ of milk $)+(12.95 \times \mathrm{kg}$ of milk fat $)+(7.20 \times \mathrm{kg}$ of milk protein $)]$.

${ }^{5}$ Feed efficiency $=3.5 \% \mathrm{FCM}(\mathrm{kg} / \mathrm{d}) / \mathrm{DMI}(\mathrm{kg} / \mathrm{d})$. 
Table 4. Corn grain-processing method and Ca salts of palm fatty acids supplementation on production and milk composition of dairy cows when fed a common diet during the carryover period (17 to 40 wk postpartum)

\begin{tabular}{|c|c|c|c|c|c|c|c|c|}
\hline Item & \multicolumn{4}{|c|}{ Treatment $^{1}$} & SEM & \multicolumn{3}{|c|}{$P$-value ${ }^{2}$} \\
\hline \multicolumn{9}{|l|}{ Yield, $\mathrm{kg} / \mathrm{d}$} \\
\hline Milk & 13.9 & 15.5 & 14.8 & 15.6 & 0.57 & 0.10 & $<0.01$ & 0.02 \\
\hline Fat & 0.60 & 0.64 & 0.62 & 0.66 & 0.08 & 0.14 & 0.01 & 0.83 \\
\hline Casein & 0.37 & 0.41 & 0.39 & 0.40 & 0.01 & 0.41 & 0.10 & 0.33 \\
\hline $3.5 \% \mathrm{FCM}^{3}$ & 15.7 & 17.0 & 16.7 & 17.4 & 0.58 & 0.10 & 0.01 & 0.74 \\
\hline $\mathrm{ECM}^{4}$ & 15.7 & 17.1 & 16.7 & 17.4 & 0.58 & 0.08 & 0.01 & 0.69 \\
\hline Cumulative milk yield, $\mathrm{kg}$ & 2,562 & 2,863 & 2,754 & 2,876 & 65.5 & 0.08 & 0.01 & 0.52 \\
\hline \multicolumn{9}{|c|}{ Milk composition, \% (unless noted) } \\
\hline Fat & 4.32 & 4.12 & 4.24 & 4.23 & 0.14 & 0.81 & 0.33 & 0.83 \\
\hline Protein & 3.42 & 3.47 & 3.34 & 3.43 & 0.08 & 0.25 & 0.73 & 0.49 \\
\hline BCS & 3.45 & 3.40 & 3.52 & 3.42 & 0.06 & 0.09 & 0.12 & 0.54 \\
\hline
\end{tabular}

${ }^{1}$ Concentrate fed during the treatment period contained either fine ground corn (FGC) or steam-flaked corn (SFC) associated or not with Ca salts of palm oil supplementation [not supplemented (CON) or supplemented (CSPO)].

${ }^{2} P$-values associated with the main effect of corn processing (corn), main effect of CSPO supplementation (fat), and the interaction between corn processing and CSPO supplementation.

${ }^{3} 3.5 \% \mathrm{FCM}=[(0.4324 \times$ milk yield $)+(16.216 \times$ fat yield $)]$.

${ }^{4} \mathrm{ECM}=[(0.327 \times \mathrm{kg}$ of milk $)+(12.95 \times \mathrm{kg}$ of milk fat $)+(7.20 \times \mathrm{kg}$ of milk protein $)]$

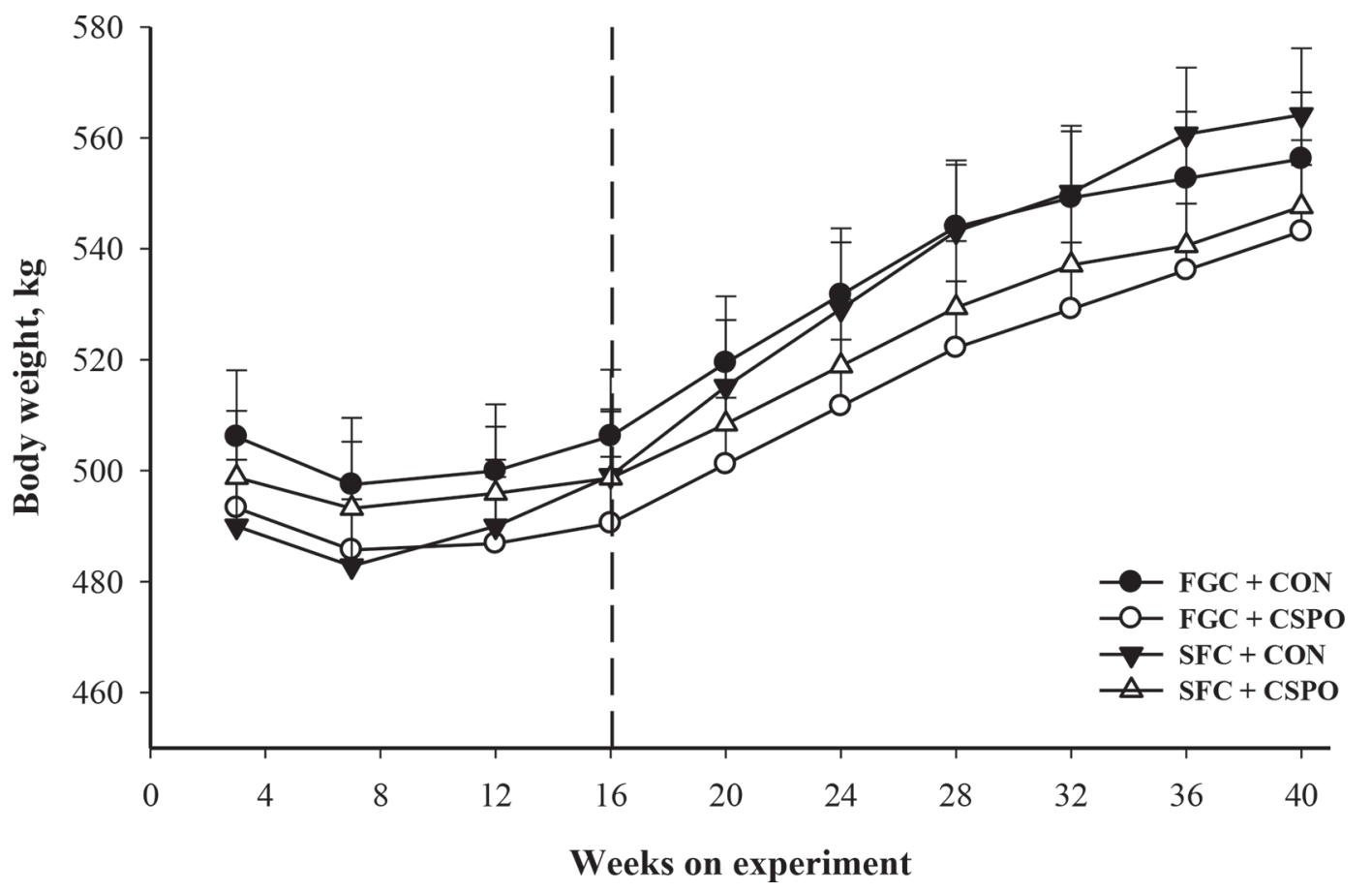

Figure 1. Effects of corn grain-processing method and supplementation with Ca salts of palm fatty acids (CSPO) on BW over time during the treatment and carryover periods. The dashed line on wk 16 indicates the start of the carryover period. Concentrate fed during the treatment period contained either fine ground corn (FGC) or steam-flaked corn (SFC) associated or not with Ca salts of palm oil supplementation [not supplemented (CON) or supplemented (CSPO)]. Error bars indicate SEM. 


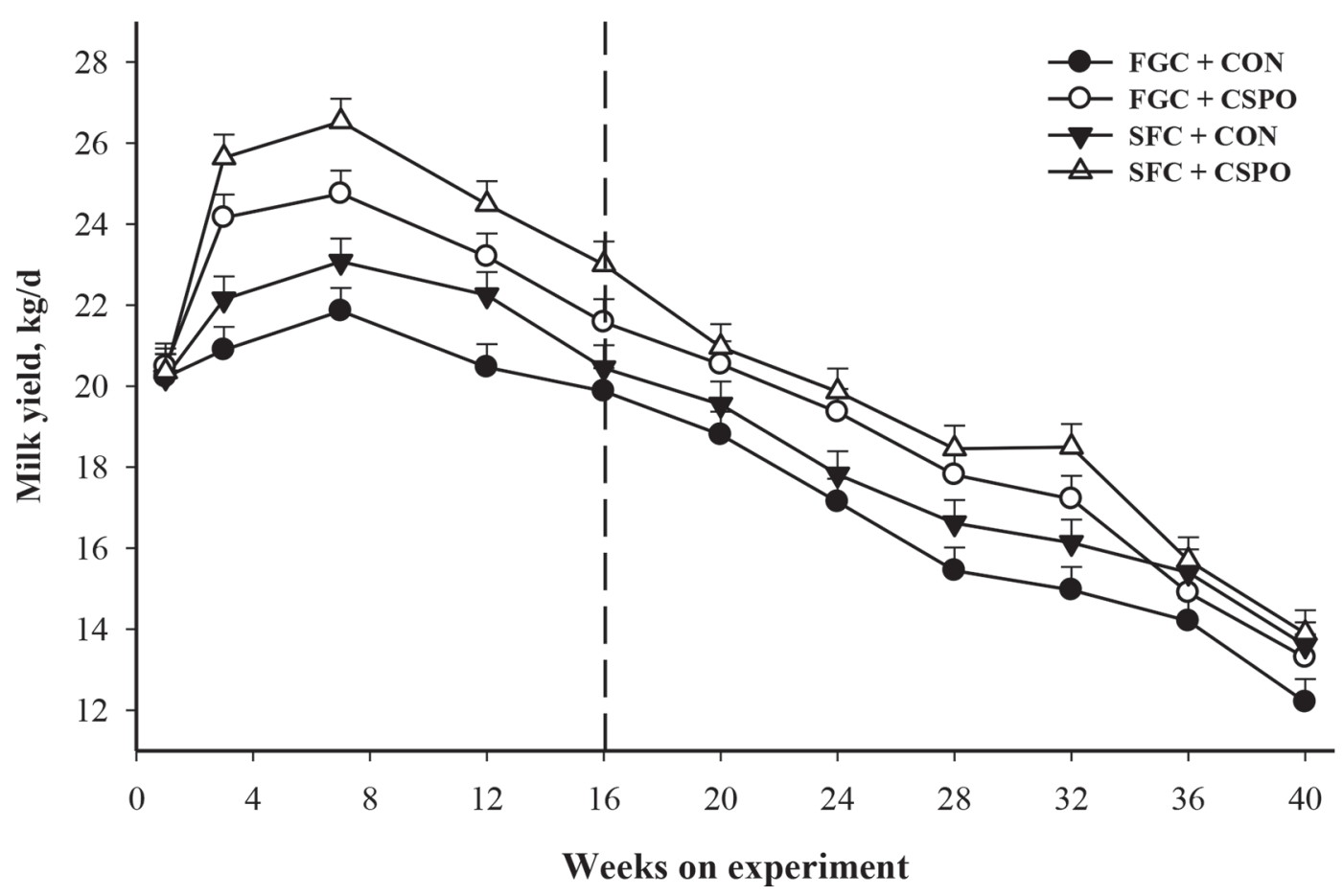

Figure 2. Effects of corn grain-processing method and supplementation with Ca salts of palm fatty acids (CSPO) on milk yield (kg/d) over time during the treatment and carryover periods. The dashed line on wk 16 indicates the start of the carryover period. Concentrate fed during the treatment period contained either fine ground corn (FGC) or steam-flaked corn (SFC) associated or not with Ca salts of palm oil supplementation [not supplemented (CON) or supplemented (CSPO)]. Error bars indicate SEM.

ryover period $(P=0.02)$, which occurred due to CSPO maintaining higher milk yield in the FGC diet but not in the SFC diet. Therefore, in the carryover period, the additive effect between SFC and CSPO that occurred in the treatment period was not maintained (Figure 2). No interactions were observed between CSPO and corn grain-processing method for milk composition and yield of milk components as well as BW and BCS $(P>0.10)$.

\section{Intake, Total-Tract Digestibility, and Feed Efficiency}

The CSPO did not affect DMI and intakes of OM, $\mathrm{CP}, \mathrm{NDF}$, and starch compared with $\mathrm{CON}(P>0.10)$. As expected, CSPO increased $(P<0.01)$ FA intake compared with CON (Table 5). Although CSPO did not affect $(P>0.10)$ the digestibility of DM, CP, NDF, and starch, it tended to increase $(P=0.07)$ the digestibility of $\mathrm{OM}$ and increase $(P<0.01)$ FA digestibility.

Corn grain-processing method did not affect DMI and intake of nutrients $(P>0.10)$. Likewise, corn grain-processing method did not affect digestibilities of $\mathrm{CP}(P=0.51)$, NDF $(P=0.45)$ and FA $(P=0.56)$. In contrast, SFC tended to increase DM digestibility (72.3 vs. $71.4 \% ; P=0.10)$ and $\mathrm{OM}$ digestibility $(73.5$ vs. $71.6 \% ; P=0.08)$ compared with FGC; SFC also increased starch digestibility compared with FGC (91.7 vs. $86.8 \% ; P<0.01)$. No interactions were observed between CSPO and corn grain-processing method for intake of nutrients and digestibility $(P>0.10)$.

\section{Energy Partitioning}

The $\mathrm{NE}_{\mathrm{L}}$ intake and milk $\mathrm{NE}_{\mathrm{L}}$ output were increased $(P \leq 0.01)$ by CSPO compared with CON (Table 6$)$. In contrast, CSPO decreased $(P=0.03) \mathrm{NE}_{\mathrm{L}}$ directed to BW change, but did not affect $(P>0.10) \mathrm{NE}_{\mathrm{L}}$ available for maintenance compared with CON. Overall, CSPO changed the energy partitioning (as percent of energy intake), directing more energy toward milk production $(P<0.01)$ and less energy to body reserves $(P=0.04)$ and maintenance $(P=0.01)$ than $\mathrm{CON}$.

The SFC increased $\mathrm{NE}_{\mathrm{L}}$ intake $(P=0.05)$ and $\mathrm{NE}_{\mathrm{L}}$ directed toward $\mathrm{BW}$ reserves $(P=0.01)$ and tended to increase $\mathrm{NE}_{\mathrm{L}}$ in milk $(P=0.09)$, whereas $\mathrm{NE}_{\mathrm{L}}$ available for maintenance were not affected $(P>0.10)$ compared with CON. Generally, SFC increased $\mathrm{NE}_{\mathrm{L}}$ partitioning toward body reserves $(P=0.02)$ and did not affect $(P$ $>0.10) \mathrm{NE}_{\mathrm{L}}$ partitioned to milk and maintenance.

We observed an interaction between CSPO and corn grain-processing method for milk $\mathrm{NE}_{\mathrm{L}}$ output $(P$ $=0.05$ ) due to CSPO increasing milk $\mathrm{NE}_{\mathrm{L}}$ output to a greater extent in the FGC diet compared with the 
Table 5. Corn grain-processing method and Ca salts of palm fatty acids supplementation on intake of nutrients and total-tract digestibility of dairy cows during the treatment period (3 to 16 wk postpartum)

\begin{tabular}{|c|c|c|c|c|c|c|c|c|}
\hline \multirow{2}{*}{ Item } & \multicolumn{4}{|c|}{ Treatment $^{1}$} & \multirow{2}{*}{ SEM } & \multirow{2}{*}{\multicolumn{3}{|c|}{$P$-value ${ }^{2}$}} \\
\hline & \multicolumn{2}{|c|}{ FGC } & \multicolumn{2}{|c|}{$\mathrm{SFC}$} & & & & \\
\hline \multicolumn{9}{|l|}{ Intake, $\mathrm{kg} / \mathrm{d}$} \\
\hline DM & 17.5 & 17.2 & 17.5 & 16.7 & 0.58 & 0.53 & 0.12 & 0.15 \\
\hline $\mathrm{OM}$ & 15.8 & 15.4 & 15.8 & 15.0 & 0.52 & 0.60 & 0.12 & 0.14 \\
\hline Starch & 4.77 & 4.59 & 4.76 & 4.69 & 0.45 & 0.54 & 0.88 & 0.68 \\
\hline Fatty acids & 0.56 & 0.81 & 0.52 & 0.82 & 0.04 & 0.88 & $<0.01$ & 0.76 \\
\hline \multicolumn{9}{|c|}{ Digestibility, \% } \\
\hline $\mathrm{DM}$ & 70.9 & 72.0 & 71.8 & 72.7 & 0.35 & 0.10 & 0.16 & 0.34 \\
\hline $\mathrm{OM}$ & 69.7 & 73.5 & 72.7 & 74.2 & 0.95 & 0.08 & 0.07 & 0.48 \\
\hline $\mathrm{CP}$ & 75.1 & 73.8 & 73.9 & 73.2 & 1.65 & 0.51 & 0.50 & 0.88 \\
\hline $\mathrm{NDF}$ & 55.7 & 53.1 & 52.1 & 55.1 & 3.31 & 0.45 & 0.54 & 0.89 \\
\hline
\end{tabular}

${ }^{1}$ Concentrate fed during the treatment period contained either fine ground corn (FGC) or steam-flaked corn (SFC) associated or not with Ca salts of palm oil supplementation [not supplemented (CON) or supplemented (CSPO)].

${ }^{2} P$-values associated with the main effect of corn processing (corn), main effect of CSPO supplementation (fat), and the interaction between corn processing and CSPO supplementation.

SFC diet. Similarly, an interaction between CSPO and corn grain-processing method was observed for energy partitioning toward milk because CSPO increased more energy partitioned to milk in the FGC diet compared with the SFC diet $(P<0.01)$. In contrast, energy partitioned to maintenance decreased more in FGC rather than SFC when CSPO was fed (interaction $P<0.01$ ).

\section{Milk FA Yields and Profile}

The CSPO increased the summation of mixed milk FA $(P=0.04)$, preformed milk FA $(P=0.05)$, and SFA $(P<0.01)$ compared with CON (Table 7$)$. The summation of de novo milk FA was reduced $(P<0.01)$ and the concentration of MUFA tended to reduce $(P=$

Table 6. Corn grain-processing method and Ca salts of palm fatty acids supplementation on energy partitioning of dairy cows during the treatment period (3 to 16 wk postpartum)

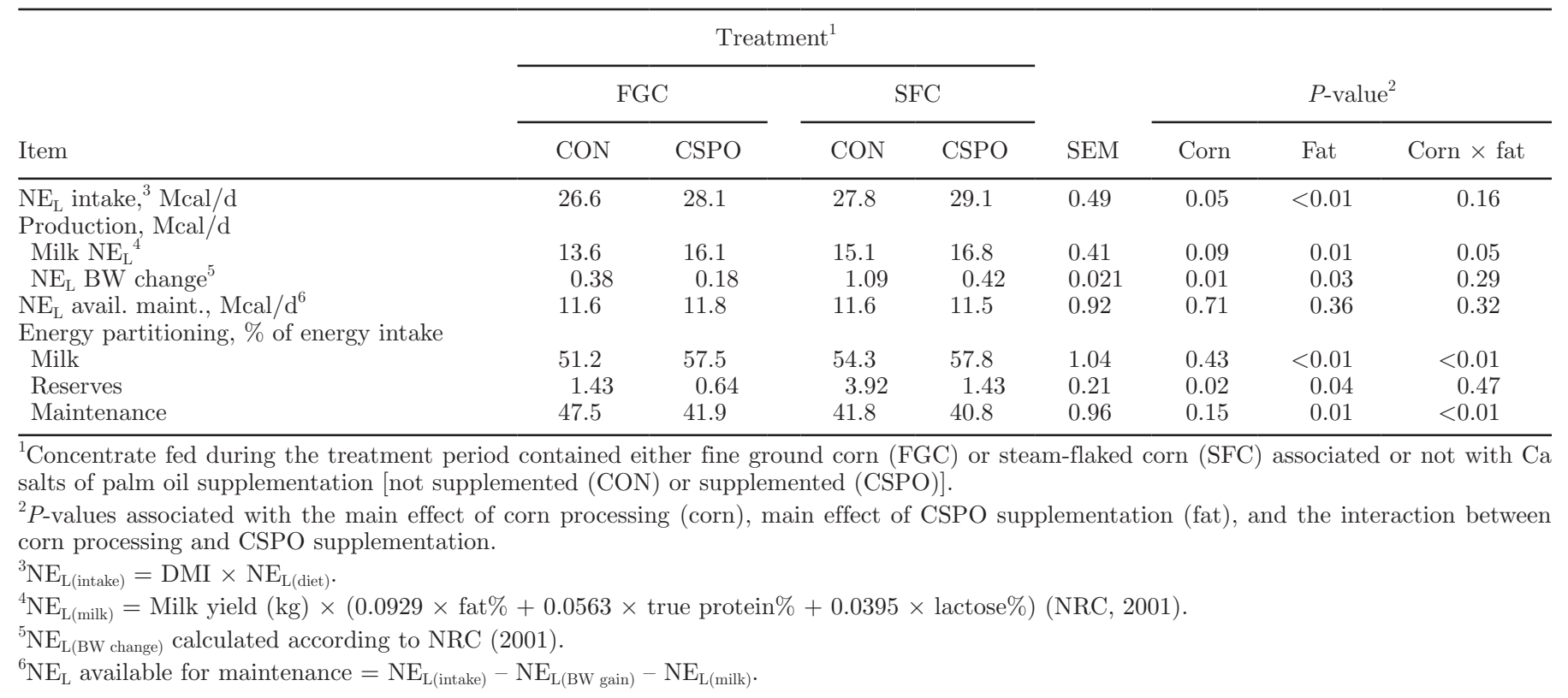


Table 7. Corn grain-processing method and Ca salts of palm fatty acids supplementation on the concentration of milk fatty acids of dairy cows during the treatment period ( 3 to 16 wk postpartum)

\begin{tabular}{|c|c|c|c|c|c|c|c|c|}
\hline \multirow{2}{*}{ Item } & \multicolumn{4}{|c|}{ Treatment $^{1}$} & \multirow{2}{*}{ SEM } & \multirow{2}{*}{\multicolumn{3}{|c|}{$P$-value ${ }^{2}$}} \\
\hline & \multicolumn{2}{|c|}{ FGC } & \multicolumn{2}{|c|}{$\mathrm{SFC}$} & & & & \\
\hline \multicolumn{9}{|l|}{ Profile, $\mathrm{g} / 100 \mathrm{~g}$ of fatty acids } \\
\hline C4:0 & 2.52 & 2.70 & 2.45 & 2.56 & 0.07 & 0.14 & 0.03 & 0.65 \\
\hline C6:0 & 1.72 & 1.59 & 1.66 & 1.55 & 0.06 & 0.40 & 0.03 & 0.98 \\
\hline $\mathrm{C} 12: 0$ & 2.19 & 1.74 & 2.61 & 1.94 & 0.16 & 0.05 & $<0.01$ & 0.44 \\
\hline C14:0 & 9.93 & 8.41 & 9.65 & 8.27 & 0.39 & 0.59 & $<0.01$ & 0.86 \\
\hline $\mathrm{C} 14: 1$ cis-9 & 0.74 & 0.57 & 0.77 & 0.62 & 0.06 & 0.37 & $<0.01$ & 0.88 \\
\hline $\mathrm{C} 15: 0$ iso & 0.31 & 0.30 & 0.30 & 0.29 & 0.01 & 0.29 & 0.22 & 0.95 \\
\hline $\mathrm{C} 15: 0$ anteiso & 0.43 & 0.39 & 0.45 & 0.41 & 0.02 & 0.39 & 0.03 & 0.88 \\
\hline C15:0 & 1.09 & 0.94 & 1.15 & 0.95 & 0.07 & 0.54 & $<0.01$ & 0.69 \\
\hline C16:0 & 26.4 & 27.7 & 26.7 & 28.8 & 0.68 & 0.42 & $<0.01$ & 0.66 \\
\hline $\mathrm{C} 18: 2$ cis -9, cis-12 & 1.61 & 1.72 & 1.83 & 1.91 & 0.10 & 0.04 & 0.33 & 0.82 \\
\hline C18:2 cis-9,trans-11 & 0.73 & 0.82 & 0.78 & 0.86 & 0.05 & 0.24 & 0.03 & 0.82 \\
\hline \multicolumn{9}{|l|}{ Summation by source ${ }^{3}$} \\
\hline$\Sigma<\mathrm{C} 16$ & 23.6 & 20.3 & 24.2 & 20.9 & 0.94 & 0.46 & $<0.01$ & 0.98 \\
\hline$\Sigma \mathrm{C} 16+\mathrm{C} 16: 1$ & 28.1 & 29.7 & 28.2 & 30.5 & 0.70 & 0.48 & 0.04 & 0.51 \\
\hline$\Sigma>\mathrm{C} 16$ & 48.2 & 50.0 & 47.6 & 51.4 & 1.34 & 0.36 & 0.05 & 0.69 \\
\hline \multicolumn{9}{|l|}{ Summation by saturation } \\
\hline$\Sigma$ Saturated & 62.1 & 64.8 & 63.2 & 63.8 & 0.64 & 0.96 & $<0.01$ & 0.22 \\
\hline$\Sigma$ Monounsaturated & 34.7 & 32.1 & 33.3 & 32.9 & 0.91 & 0.75 & 0.09 & 0.21 \\
\hline$\Sigma$ Polyunsaturated & 3.28 & 3.14 & 3.51 & 3.33 & 0.10 & 0.02 & 0.19 & 0.99 \\
\hline
\end{tabular}

${ }^{1}$ Concentrate fed during the treatment period contained either fine ground corn (FGC) or steam-flaked corn (SFC) associated or not with Ca salts of palm oil supplementation [not supplemented (CON) or supplemented (CSPO)].

${ }^{2} P$-values associated with the main effect of corn processing (corn), main effect of CSPO supplementation (fat), and the interaction between corn processing and CSPO supplementation.

${ }^{3}$ De novo fatty acids originate from mammary de novo synthesis ( $<16$ carbons), preformed fatty acids originate from extraction from plasma (>16 carbons), and mixed fatty acids originate from both sources (C16:0 plus cis-9 C16:1).

0.09) in CSPO compared with CON. Although CSPO did not affect the yield of de novo milk FA (Table 8; $P$ $>0.10)$, it increased $(P \leq 0.05)$ the yield of mixed milk FA, preformed FA, SFA, and MUFA in milk than CON.

Corn grain-processing method did not affect summation by source of milk FA and the concentration of SFA and MUFA $(P>0.10)$. The SFC increased the concentration of PUFA $(P=0.02)$ and the yield of PUFA $(P=0.05)$ compared with FGC. Although corn grain-processing method did not affect the concentration of most individual FA (Table 7), SFC increased the yield of some MUFA and PUFA compared with FGC (Table 8). No interactions were observed between CSPO and corn grain-processing method for milk FA yields and profiles $(P>0.10)$.

\section{DISCUSSION}

The recent adoption of intensive management grazing practices has improved the nutritive value of tropi- cal grasses (Da Silva et al., 2013) and animal performance (Voltolini et al., 2010). Nonetheless, the higher NDF content of tropical grasses and the possible low particle fragility are major limitations to forage intake and performance. Hence, energy intake is most likely the major restriction to better performance in pasturebased systems (Hills et al., 2015). To overcome these limitations, we evaluated whether corn grain-processing method and fat supplementation interact during early lactation increasing energy intake and performance, and the potential carryover effects throughout lactation on production responses.

Depending on the stage of lactation, an increase in energy density due to fat supplementation could increase milk production, milk fat yield, and body reserves as long as dietary fat supplements do not reduce DMI or negatively affect the digestibility of other nutrients (Boerman et al., 2015). The effect of fat supplements on DMI is variable and usually depends on the type of fat being fed (Rabiee et al., 2012). In our study, DMI was 
not affected by CSPO supplementation, which agrees with a recent study feeding CSPO to early-lactation grazing cows (de Souza et al., 2017). Also, we observed that CSPO increased FA digestibility and tended to increase OM digestibility; this increase in FA digestibility is possibly associated with the FA profile of CSPO supplement, as UFA have higher digestibility than SFA (Boerman et al., 2015). Therefore, the positive effects of CSPO supplementation on FA digestibility, with no effect on DMI, resulted in greater $\mathrm{NE}_{\mathrm{L}}$ intake for CSPO-supplemented diets and better milk production responses during the treatment period.

In addition, we did not observe effects of corn grainprocessing method on DMI. Oba and Allen (2003) observed that a more rapidly fermentable starch source (high-moisture corn) reduced feed intake by $8 \%$ of mid-lactation cows compared with a less fermentable starch source (dry ground corn) by decreasing meal size. Similar to our results, Theurer et al. (1999) and
Ferrareto et al. (2013) did not observe differences in DMI between steam-flaked corn and dry ground or rolled corn. Although corn grain-processing method did not affect fiber digestibility in our study, Theurer et al. (1999) noted that steam-flaking corn decreased fiber digestibility by $16 \%$. Corroborating our findings, Ferrareto et al. (2013) did not observe differences in fiber digestibility between steam-flaked corn and dry ground or rolled corn. We observed that SFC increased total-tract starch digestibility by $5 \%$ units compared with FGC, which is greater than the $2 \%$ units improvement reported by Ferrareto et al. (2013) when comparing steam-flaked corn and dry ground or rolled corn. These differences might be associated with the kernel vitreousness, as grain vitreousness is negatively correlated with total-tract starch digestibility (Correa et al., 2002; Lopes et al., 2009). Similarly, with beef cattle, Gouvêa et al. (2016) reported that steam-flaking of flint corn resulted in marked improvements in animal

Table 8. Corn grain-processing method and Ca salts of palm fatty acids supplementation on milk fatty acids yield of dairy cows during the treatment period (3 to 16 wk postpartum)

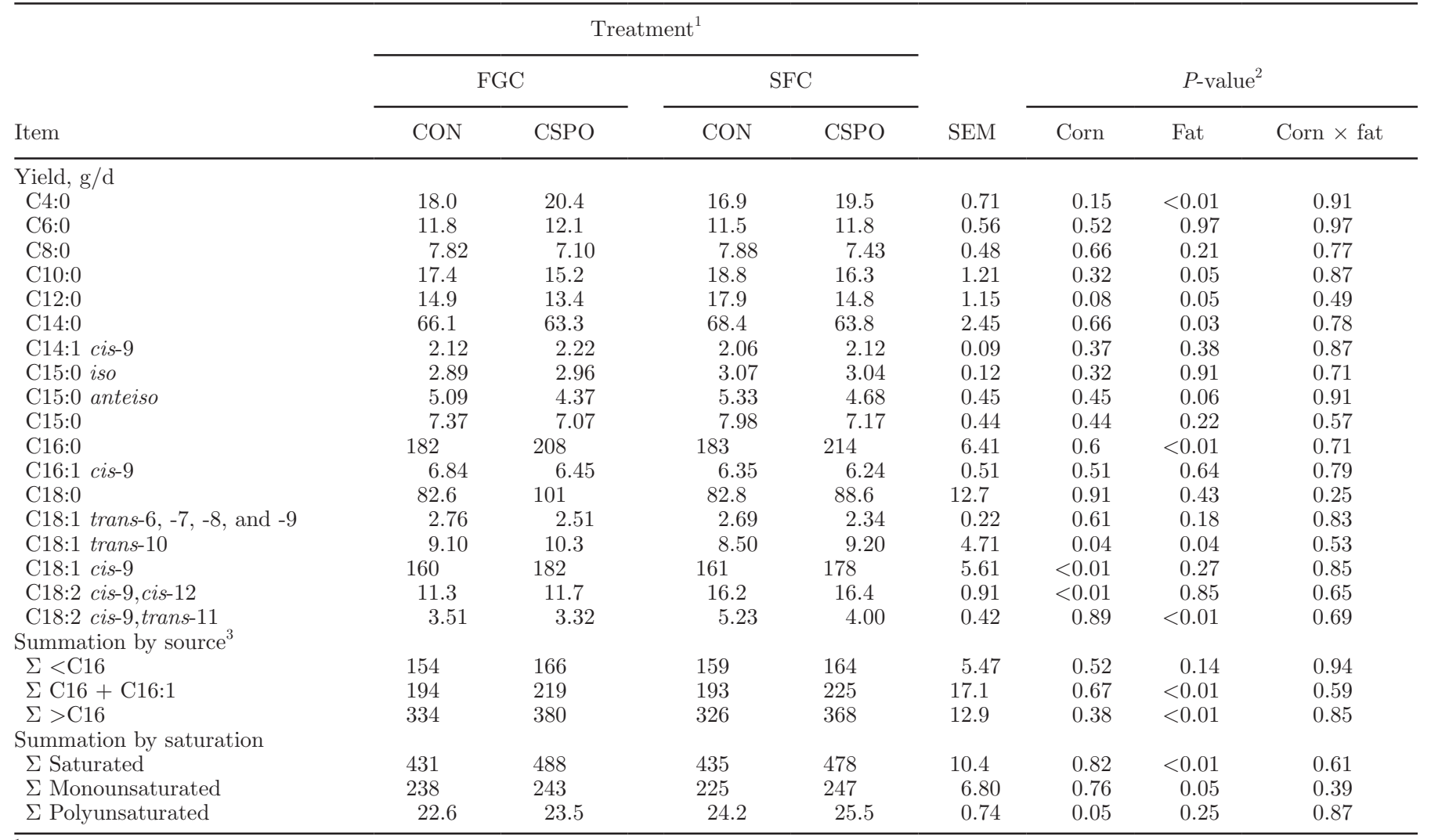

${ }^{1}$ Concentrate fed during the treatment period contained either fine ground corn (FGC) or steam-flaked corn (SFC) associated or not with Ca salts of palm oil supplementation [not supplemented (CON) or supplemented (CSPO)].

${ }^{2} P$-values associated with the main effect of corn processing (corn), main effect of CSPO supplementation (fat), and the interaction between corn processing and CSPO supplementation.

${ }^{3}$ De novo fatty acids originate from mammary de novo synthesis ( $<16$ carbons), preformed fatty acids originate from extraction from plasma (>16 carbons), and mixed fatty acids originate from both sources (C16:0 plus cis-9 C16:1). 
performance and those responses to the flaking of flint corn were considerably greater than reported in the published literature for flaking of dent corn grain (Zinn et al., 2011). According to McAllister et al. (2007), the benefits of steam-flaking on digestion of corn are related to an increased surface area of grains and gelatinization of the starch due to denaturation of the protein matrix. Therefore, the greater beneficial effects of flaking for flint corn than for dent corn matches our hypothesis, that the benefit of steam-flaking should be greater for the flint corn, as used in the present study, than commonly is observed for dent corn in trials from North America (Owens and Basalan, 2013). Also, our results indicate that increasing corn grain-processing method of flint corn increased energy intake due to the increase in total-tract starch digestibility.

In our study, during the treatment period CSPO increased milk yield in both the FGC and SFC diets. The positive effect of fat supplementation on milk production has been reported in both housed animals receiving TMR (Rabiee et al., 2012) and grazing animals (Schroeder et al., 2004). This effect could be associated with the greater energy density of the fat-supplemented diets providing more energy for metabolic functions. Fat supplementation also increases energetic efficiency in lactating cows by increasing total energy intake, by generating ATP more efficiently compared with VFA, and by direct incorporation of long-chain FA into milk fat (Palmquist, 1994). Schroeder et al. (2004) compiled 18 studies feeding different fat supplements to cows grazing on temperate pastures and observed that supplemental fat increased milk yield, on average, by $5 \%$. As high-producing dairy cows grazing on tropical pastures likely have lower energy intake due to the reduced nutritive value and forage intake of tropical pastures compared with temperate pastures (Da Silva et al., 2013), they probably are more responsive to energy supplementation (de Souza et al., 2017). This possibly explains the greater milk yield response in our study to supplemental fat when compared with Schroeder et al. (2004).

As we hypothesized, CSPO increased milk yield and ECM, but also tended to increase to a greater extent in the FGC (18.2\%) than the SFC (12.5\%) diet during the treatment period. In addition, we observed a tendency for an interaction between CSPO and corn grain-processing method for $\mathrm{BW}$ change and BCS due to CSPO, which reduced them in the FGC diet but had no effect in the SFC diet. These results indicate an interaction between fat supplementation and corn grainprocessing method on energy partitioning of dairy cows. Similarly, Weiss and Pinos-Rodríguez (2009) observed that when high-forage diets were supplemented with fat, the increased $\mathrm{NE}_{\mathrm{L}}$ intake was partitioned toward body energy reserves; whereas when low-forage diets were supplemented with fat, milk yield increased with no change in body reserves. Our results corroborate this hypothesis and suggest that corn grain-processing method also might alter energy partitioning. Additionally, the greater benefit of CSPO supplementation in the FGC diet supports the concept that extensive grain processing (i.e., steam-flaking) increases the energetic value of corn grain (Zinn et al., 2007) and explains the greater milk yield response to CSPO supplementation with the FGC diet. Altogether, our results demonstrated that CSPO increased milk yield and ECM in cows grazing tropical pastures, but also corroborated our initial hypothesis that the magnitude of the response is affected by corn grain-processing method. Additionally, we observed that CSPO supplementation increased yield of milk components during the treatment period. The increase in fat yield by CSPO supplementation was mainly result of the increase in yield of C16:0 and C16:1 cis-9. This result was likely associated with the greater amount of C16:0 in our fat supplement, as recent studies feeding C16:0-enriched supplements have shown that C16:0 consistently increase milk fat yield (Lock et al., 2013; Piantoni et al., 2013).

Changes in feeding level during early lactation not only have an immediate effect on production, but level of nutrition during the first few weeks of lactation can have a major effect on subsequent lactation performance (Jørgensen et al., 2016). One of our goals was to evaluate the potential carryover effect of corn grain-processing method and fat supplementation to early-lactation cows throughout lactation. The carryover effect may be important in determining the economic impact of specific feeding strategies, as fat supplementation and more fermentable sources of starch are generally expensive compared with other dietary components or ingredients. Usually, each extra kilogram of milk secreted at peak production results in approximately $200 \mathrm{~kg}$ of milk subsequent during lactation (Roche et al., 2013), suggesting that supplementation during early lactation that increases milk production at peak could have positive effects even though supplementation ceased. In our study, we observed that fat supplementation had a positive carryover effect on milk yield and increased cumulative milk yield by $8.0 \%$, whereas SFC also tended to increase cumulative milk yield by $3.8 \%$ compared with FGC. Similarly, de Souza et al. (2017) observed that feeding supplemental fat to grazing cows had a positive carryover effect on milk yield, but the magnitude of the response was affected by the FA profile of the fat supplement. Our results also agree with a recent review in which most results showed that a more 
generous energy feeding strategy during early lactation caused a positive carryover effect on subsequent production (Jørgensen et al., 2016). Interestingly, our results suggest that the source of energy (glucogenic vs. lipogenic precursors) affect the magnitude of the carryover effect. The possible explanations for the carryover effect on milk yield involve either an increase in mammary cell number (Akers, 2002) or cell secretory activity (Nørgaard et al., 2005). The expansion of epithelial cell populations in the mammary gland is mainly regulated by ovarian steroids, in particular estrogen (Arendt and Kuperwasser, 2015). In rodents, flaxseed oil was shown to alter mammary development (Tou and Thompson, 1999), modify mammary gland morphology, and increase the number of estradiol receptor binding sites in the mammary gland of mice (Hilakivi-Clarke et al., 1998). Although evidence exists that FA can increase mammary cell number in rodents, to our knowledge this has not been evaluated in dairy cows. Based on our study and the study of de Souza et al. (2017), supplementation with CSPO at early lactation has positive carryover effect on milk yield. However, further studies are needed to comprehend factors associated with carryover effects and to determine the duration and magnitude of this under different dietary conditions.

Although CSPO supplementation increased milk production during the carryover period, we observed an interaction between CSPO and corn grain-processing method for milk yield due to CSPO maintaining higher milk yield in the FGC diet but not the SFC diet. Therefore, the additive effect between SFC and CSPO that occurred in the treatment period was not maintained throughout carryover period. These results are probably associated with the tendency for SFC diets to increase BW and BCS during the carryover period. The association between the general shape of the lactation curve and calving BCS as well as BCS change between calving and nadir is nonlinear (Roche et al., 2009b). Roche et al. (2007) reported such nonlinear associations, with lactation milk yield increasing with BCS loss postcalving, up to 0.5 BCS units, and decreasing with further BCS loss. Although feeding SFC reduced BW and BCS loss and improved energy balance during early lactation, this faster recovery of body condition is likely important to improve reproductive performance. However, cows that gain excessive BCS in mid and late lactation are at a higher risk for culling in the subsequent lactation due to increased incidence of metabolic diseases and reproductive failure (Roche et al., 2009a). Therefore, further research is needed to evaluate the association between diets that improve energy balance at early lactation, carryover effects, and reproductive performance.

\section{CONCLUSIONS}

In conclusion, corn grain-processing method interacted with CSPO supplementation on production responses and had a carryover effect in grazing cows. When CSPO was fed in the FGC diet, milk production increased more than when fed in the SFC diet, but also caused greater mobilization of reserves at early lactation. Furthermore, supplementations with both CSPO and SFC were effective strategies to increase energy intake and yields of milk and milk solids. The carryover effect on milk production was greater for CSPO supplementation than altering corn grain-processing method, whereas SFC diets had lower mobilization of reserves and less BW and BCS variation throughout lactation.

\section{ACKNOWLEDGMENTS}

This study and scholarships were supported by The State of São Paulo Research Foundation (FAPESP, São Paulo, Brazil). We wish to acknowledge Márcio Rezende Ribeiro Soares, Mateus Mendes Vilanova e Silva, Caroline Salles de Miranda Motta, Pâmela Domingues de Andrade, and Evangelina Miqueo (all from The University of São Paulo) for their assistance in this experiment. In addition, the authors express their gratitude to Nutricorp (Araras, São Paulo, Brazil) and Cargill (Campinas, São Paulo, Brazil) for their partial financial support.

\section{REFERENCES}

Akers, R. M. 2002. Lactation and the Mammary Gland. Iowa State University Press, Ames.

AOAC International. 2005. Official Methods of Analysis. 18th ed. AOAC International, Gaithersburg, MD.

Arendt, L. M., and C. Kuperwasser. 2015. Form and function: How estrogen and progesterone regulate the mammary epithelial hierarchy. J. Mammary Gland Biol. Neoplasia 20:9-25.

Auldist, M. J., L. C. Marett, J. S. Greenwood, M. Hannah, J. L. Jacobs, and W. J. Wales. 2013. Effects of different strategies for feeding supplements on milk production responses in cows grazing a restricted pasture allowance. J. Dairy Sci. 96:1218-1231.

Bargo, F., L. D. Muller, E. S. Kolver, and J. E. Delahoy. 2003. Invited review: Production and digestion of supplemented dairy cows on pasture. J. Dairy Sci. 86:1-42.

Boerman, J. P., S. B. Potts, M. J. VandeHaar, and A. L. Lock. 2015 Effects of partly replacing dietary starch with fiber and fat on milk production and energy partitioning. J. Dairy Sci. 98:7264-7276.

Chouinard, P. Y., L. Corneau, A. Sæbø, and D. E. Bauman. 1999. Milk yield and composition during abomasal infusion of conjugated linoleic acids in dairy cows. J. Dairy Sci. 82:2737-2745.

Christie, W. W. 1982. A simple procedure for rapid transmethylation of glycerolipids and cholesterol esters. J. Lipid Res. 23:1072-1075.

Correa, C. E. S., R. D. Shaver, M. N. Pereira, J. G. Lauer, and K. Kohn. 2002. Relationship between corn vitreousness and ruminal in situ starch degradability. J. Dairy Sci. 85:3008-3012.

Da Silva, S. C., F. M. A. Gimenes, D. O. L. Sarmento, A. F. Sbrissia, D. E. Oliveira, A. Hernadez-Garay, and A. V. Pires. 2013. Grazing behaviour, herbage intake and animal performance of beef cattle 
heifers on Marandu palisadegrass subjected to intensities of continuous stocking management. J. Agric. Sci. 151:727-739.

de Souza, J., F. Batistel, and F.A.P. Santos. 2017. Effect of sources of Ca salts of fatty acids on production, nutrient digestibility, energy balance, and carryover effects of early lactation grazing dairy cows. J. Dairy Sci. 100:1072-1085.

de Souza, J., F. Batistel, K. C. Welter, M. M. V. Silva, D. F. Costa, and F. A. P. Santos. 2015. Evaluation of external markers to estimate fecal excretion, intake and digestibility in dairy cows. Trop. Anim. Health Prod. 47:265-268.

De Vries, M. F. W. 1995. Estimating forage intake and quality in grazing cattle: A reconsideration of the hand-plucking method. J. Range Manage. 48:370-375.

Dohme-Meier, F., L. D. Kaufmann, S. Görs, P. Junghans, C. C. Metges, H. A. van Dorland, R. M. Bruckmaier, and A. Münger. 2014 Comparison of energy expenditure, eating pattern and physical activity of grazing and zero-grazing dairy cows at different time points during lactation. Livest. Sci. 162:86-96.

Ferraretto, L. F., P. M. Crump, and R. D. Shaver. 2013. Effect of cereal grain type and corn grain harvesting and processing methods on intake, digestion, and milk production by dairy cows through a meta-analysis. J. Dairy Sci. 96:533-550.

Glasser, F., M. Doreau, A. Ferlay, and Y. Chilliard. 2007. Technical note: Estimation of milk fatty acid yield from milk fat data. J. Dairy Sci. 90:2302-2304.

Gouvêa, V. N., F. Batistel, J. de Souza, L. J. Chagas, C. Sitta, P. R. B. Campanili, D. B. Galvani, A. V. Pires, F. N. Owens, and F. A. P. Santos. 2016. Flint corn grain processing and citrus pulp level in finishing diets for feedlot cattle. J. Anim. Sci. 94:665-677.

Hara, A., and N. S. Radin. 1978. Lipid extraction with low-toxicity solvent. Anal. Biochem. 90:420-426.

Harvatine, K. J., and M. S. Allen. 2006. Effects of fatty acid supplements on milk yield and energy balance of lactating dairy cows. J. Dairy Sci. 89:1081-1091.

Harvatine, K. J., J. W. Perfield, and D. E. Bauman. 2009. Expression of enzymes and key regulators of lipid synthesis is upregulated in adipose tissue during CLA-induced milk fat depression in dairy cows. J. Nutr. 139:849-854.

Hilakivi-Clarke, L., A. Stoica, M. Raygada, and M. Martin. 1998. Consumption of a high-fat diet alters estrogen receptor content, protein kinase $\mathrm{C}$ activity, and mammary gland morphology in virgin and pregnant mice and female offspring. Cancer Res. 58:654-660.

Hills, J. L., W. J. Wales, F. R. Dunshea, S. C. Garcia, and J. R. Roche 2015. Invited review: An evaluation of the likely effects of individualized feeding of concentrate supplements to pasture-based dairy cows. J. Dairy Sci. 98:1363-1401.

Huhtanen, P., K. Kaustell, and S. Jaakkola. 1994. The use of internal markers to predict total digestibility and duodenal flow of nutrients in cattle given six different diets. Anim. Feed Sci. Technol. $48: 211-227$.

Jørgensen, C. H., R. Spörndly, J. Bertilsson, and S. Østergaard. 2016. Invited review: Carryover effects of early lactation feeding on total lactation performance in dairy cows. J. Dairy Sci. 99:3241-3249.

Karkalas, J. 1985. An improved enzymatic method for the determination of native and modified starch. J. Sci. Food Agric. 36:10191027.

Krause, K. M., and D. K. Combs. 2003. Effects of forage particle size, forage source, and grain fermentability on performance and ruminal $\mathrm{pH}$ in mid lactation cows. J. Dairy Sci. 86:1382-1397.

Lascano, G. J., M. Alende, L. E. Koch, and T. C. Jenkins. 2016. Changes in fermentation and biohydrogenation intermediates in continuous cultures fed low and high levels of fat with increasing rates of starch degradability. J. Dairy Sci. 99:6334-6341.

Lock, A. L., C. L. Preseault, J. E. Rico, K. E. DeLand, and M. S. Allen. 2013. Feeding a C16:0-enriched fat supplement increased the yield of milk fat and improved conversion of feed to milk. J. Dairy Sci. 96:6650-6659.

Lopes, J. C., R. D. Shaver, P. C. Hoffman, M. S. Akins, S. J. Bertics, H. Gencoglu, and J. G. Coors. 2009. Type of corn endosperm influences nutrient digestibility in lactating dairy cows. J. Dairy Sci. 92:4541-4548.
McAllister, T. A., D. J. Gibb, K. A. Beauchemin, and Y. Wang. 2007. Starch type, structure and ruminal digestion. Pages 30-41 in Proc. Cattle Grain Process. Symp., Tulsa, OK. Accessed Dec. 1, 2016. http://beefextension.com/proceedings/cattle_grains06/06-5.pdf.

McCarthy, M. M., T. Yasui, C. M. Ryan, G. D. Mechor, and T. R. Overton. 2015. Performance of early-lactation dairy cows as affected by dietary starch and monensin supplementation. J. Dairy Sci. 98:3335-3350.

Moore, J. E., and G. O. Mott. 1973. Structural inhibitors of quality in tropical grasses. Pages 53-98 in Anti-Quality Components of Forages. Special publication, vol. 4. A. G. Matches, ed. CSSA, Madison, WI

Muller, L. D., and S. L. Fales. 1998. Supplementation of cool-season grass pastures for dairy cattle. Pages 335-350 in Grass for Dairy Cattle. J. H. Cherney and D. J. R. Cherney, ed. CAB International, Wallingford, UK.

Myers, W. D., P. A. Ludden, V. Nayigihugu, and B. W. Hess. 2004 Technical note: A procedure for preparation and quantitative analysis of samples for titanium dioxide. J. Anim. Sci. 82:179-183.

Nørgaard, J., A. Sorensen, M. T. Sørensen, J. B. Andersen, and K. Sejrsen. 2005. Mammary cell turnover and enzyme activity in dairy cows: Effects of milking frequency and diet energy density. J. Dairy Sci. 88:975-982.

NRC. 2001. Nutrient Requirements of Dairy Cattle. 7th rev. ed. Natl. Acad. Sci., Washington, DC.

Oba, M., and M. S. Allen. 2003. Effects of corn grain conservation method on ruminal digestion kinetics for lactating dairy cows at two dietary starch concentrations. J. Dairy Sci. 86:184-194.

Owens, F. N., and M. Basalan. 2013. Grain processing: Gain and efficiency responses by feedlot cattle. Pages 76-100 in Proc. Plains Nutr. Counc., Amarillo, TX. Accessed Dec. 1, 2016. http:// amarillo.tamu.edu/files/2010/10/2013-proceedings.pdf.

Owens, F. N., and S. Soderlund. 2007. Ruminal and post ruminal starch digestion by cattle. Pages 116-128 in Proc. Cattle Grain Process. Symp., Tulsa, OK. Accessed Dec. 1, 2016. http://beefextension. $\mathrm{com} /$ proceedings/cattle_grains06/06-17.pdf.

Palmquist, D. L. 1994. The role of dietary fats in efficiency of ruminants. J. Nutr. 124:1377S-1382S.

Philippeau, C., and B. Michalet-Doreau. 1998. Influence of genotype and ensiling of corn grain on in situ degradation of starch in the rumen. J. Dairy Sci. 81:2178-2184.

Piantoni, P., A. L. Lock, and M. S. Allen. 2013. Palmitic acid increased yields of milk and milk fat and nutrient digestibility across production level of lactating cows. J. Dairy Sci. 96:7143-7154.

Rabiee, A. R., K. Breinhild, W. Scott, H. M. Golder, E. Block, and I. J. Lean. 2012. Effect of fat additions to diets of dairy cattle on milk production and components: A meta-analysis and metaregression. J. Dairy Sci. 95:3225-3247.

Roche, J. R., N. C. Friggens, J. K. Kay, M. W. Fisher, K. J. Stafford, and D. P. Berry. 2009b. Invited review: Body condition score and its association with dairy cow productivity, health, and welfare. J. Dairy Sci. 92:5769-5801.

Roche, J. R., J. K. Kay, A. G. Rius, T. M. Grala, A. J. Sheahan, H. M. White, and C. V. C. Phyn. 2013. Short communication: Immediate and deferred milk production responses to concentrate supplements in cows grazing fresh pasture. J. Dairy Sci. 96:2544-2550.

Roche, J. R., J. M. Lee, K. A. Macdonald, and D. P. Berry. 2007 Relationships among body condition score, body weight, and milk production variables in pasture-based dairy cows. J. Dairy Sci. 90:3802-3815.

Roche, J. R., L. R. Turner, J. M. Lee, D. C. Edmeades, D. J. Donaghy, K. A. Macdonald, J. W. Penno, and D. P. Berry. 2009a. Weather herbage quality and milk production in pastoral systems. 2. Temporal patterns and intra-relationships in herbage quality and mineral concentration parameters. Anim. Prod. Sci. 49:200-210.

Santos, F. A. P., J. R. R. Dórea, J. de Souza, F. Batistel, and D. F. A. Costa. 2014. Forage management and methods to improve nutrient intake in grazing cattle. Pages 144-164 in Proc. 25th Annu. Florida Rumin. Nutr. Symp. Univ. Florida, Gaineville. 
Schauff, D. J., J. P. Elliott, J. H. Clark, and J. K. Drackley. 1992. Effects of feeding lactating dairy cows diets containing whole soybeans and tallow. J. Dairy Sci. 75:1923-1935.

Schroeder, G. F., G. A. Gagliostro, F. Bargo, J. E. Delahoy, and L. D. Muller. 2004. Effects of fat supplementation on milk production and composition by dairy cows on pasture: a review. Livest. Prod. Sci. 86:1-18.

Sukhija, P. S., and D. L. Palmquist. 1990. Dissociation of Ca soaps of long-chain fatty acids in rumen fluid. J. Dairy Sci. 73:1784-1787.

Theurer, C. B., J. T. Huber, A. Delgado-Elorduy, and R. Wanderley. 1999. Invited review: Summary of steam-flaking corn or sorghum grain for lactating dairy cows. J. Dairy Sci. 82:1950-1959.

Tou, J. C. L., and L. U. Thompson. 1999. Exposure to flaxseed or its lignan component during different developmental stages influences rat mammary gland structures. Carcinogenesis 20:1831-1835.

Van Soest, P. J., J. B. Robertson, and B. A. Lewis. 1991. Methods for dietary fiber, neutral detergent fiber and nonstarch polysaccharides in relation to animal nutrition. J. Dairy Sci. 74:3583-3597.

Voltolini, T. V., F. A. P. Santos, J. C. Martinez, H. Imaizumi, R. L. Clarindo, and M. A. Penati. 2010. Milk production and composition of dairy cows grazing elephant grass under two grazing intervals. Braz. J. Anim. Sci. 39:121-127.
Wales, W. J., and P. T. Doyle. 2003. Effect of grain and straw supplementation on marginal milk production responses and rumen function of cows grazing highly digestible subterranean clover pasture. Aust. J. Exp. Agric. 43:467-474.

Wales, W. J., E. S. Kolver, P. L. Thorne, and A. R. Egan. 2004. Diurnal variation in ruminal $\mathrm{pH}$ on the digestibility of highly digestible perennial ryegrass during continuous culture fermentation. J. Dairy Sci. 87:1864-1871.

Weiss, W. P., and J. M. Pinos-Rodríguez. 2009. Production responses of dairy cows when fed supplemental fat in low- and high-forage diets. J. Dairy Sci. 92:6144-6155.

Wildman, E. E., G. M. Jones, P. E. Wagner, R. L. Boman, H. F. Troutt Jr., and T. N. Lesch. 1982. A dairy cow body condition scoring system and its relationship to selected production characteristics. J. Dairy Sci. 65:495-501.

Zinn, R. A., A. Barreras, L. Corona, F. N. Owens, and A. Plascencia. 2011. Comparative effects of processing methods on the feeding value of maize in feedlot cattle. Nutr. Res. Rev. 24:183-190.

Zinn, R. A., A. Barreras, L. Corona, F. N. Owens, and R. A. Ware. 2007. Starch digestion by feedlot cattle: Predictions from analysis of feed and fecal starch and nitrogen. J. Anim. Sci. 85:1727-1730. 